\title{
Analysis of expressed sequence tags from Citrus sinensis L. Osbeck infected with Xylella fastidiosa
}

\author{
Alessandra A. de Souza ${ }^{1}$, Marco A. Takita ${ }^{1,2}$, Helvécio D. Coletta-Filho ${ }^{1}$, Maria Luisa P.N. Targon ${ }^{1}$, \\ Eduardo F. Carlos ${ }^{1}$, Eliane C. Locali-Fabris ${ }^{1}$, Alexandre M. Amaral ${ }^{1,3}$, Juliana Freitas-Astúa ${ }^{1,4}$, \\ Ana Carla O. Silva-Pinhati ${ }^{1}$, Raquel L. Boscariol-Camargo ${ }^{1}$, Irving J. Berger ${ }^{1}$, \\ Carolina M. Rodrigues ${ }^{1}$, Marcelo S. Reis ${ }^{1}$ and Marcos A. Machado ${ }^{1}$ \\ ${ }^{1}$ Centro APTA Citros Sylvio Moreira, Instituto Agronômico de Campinas, Cordeirópolis, SP, Brazil. \\ ${ }^{2}$ Centro de Pesquisa e Desenvolvimento de Recursos Genéticos Vegetais, \\ Instituto Agronomico de Campinas, Campinas,SP, Brazil. \\ ${ }^{3}$ Embrapa Recursos Genéticos e Biotecnologia, Brasília, DF, Brazil. \\ ${ }^{4}$ Embrapa Mandioca e Fruticultura Tropical, Cruz das Almas, BA, Brazil.
}

\begin{abstract}
In order to understand the genetic responses resulting from physiological changes that occur in plants displaying citrus variegated chlorosis (CVC) symptoms, we adopted a strategy of comparing two EST libraries from sweet orange [Citrus sinensis (L.) Osbeck]. One of them was prepared with plants showing typical CVC symptoms caused by Xylella fastidiosa and the other with non-inoculated plants. We obtained 15,944 ESTs by sequencing the two cDNA libraries. Using an in silico hybridization strategy, 37 genes were found to have significant variation at the transcriptional level. Within this subset, 21 were up-regulated and 16 were down-regulated in plants with CVC. The main functional categories of the down-regulated transcripts in plants with CVC were associated with metabolism, protein modification, energy and transport facilitation. The majority of the up-regulated transcripts were associated with metabolism and defense response. Some transcripts associated with adaptation to stress conditions were up-regulated in plants with CVC and could explain why plants remain alive even under severe water and nutritional stress. Others of the up-regulated transcripts are related to defense response suggesting that sweet orange plants activate their defense machinery. The genes associated with stress response might be expressed as part of a secondary response related to physiological alterations caused by the infection.
\end{abstract}

Key words: sweet orange, EST, CVC, compatible interaction.

Received: July 24, 2006; Accepted: March 6, 2007.

\section{Introduction}

The citrus industry is one of most important agribusinesses in Brazil, with highly organized segments and competitive initiatives. The Brazilian citrus industry returns an annual gross income of around 1.5 billion dollars, from exports of concentrated juice and orange sub-products such as pectin, oil, and animal food (http://www.abecitrus.com.br).

Citrus diseases can be considered the most limiting factor to increasing and sustaining productivity in Brazil. Today, the citrus variegated chlorosis (CVC), caused by Xylella fastidiosa, is one of the most important diseases affecting the citrus culture. Epidemiological studies demon-

Send correspondence to Alessandra Alves de Souza. Centro APTA Citros Sylvio Moreira, Instituto Agronômico de Campinas, Rod. Anhanguera km 158, Caixa Postal 4, 13490-970 Cordeirópolis, SP, Brazil. E-mail: alessandra@centrodecitricultura.br. strated that around $40 \%$ of sweet orange groves in São Paulo State have trees with CVC (www.fundecitrus. com. br), which causes annual losses of about US $\$ 100$ million to the citrus industry. The CVC symptoms include leaf mottled chlorosis, with leaves generally smaller than those from non-inoculated plants and with lower zinc and potassium levels, stunted canopy, twig die-back, and production of small fruits with a very hard rind that is normally rejected by the juice processing plants (Rossetti et al., 1990; Gomes et al., 2003). The symptoms occur as a result of the $X$. fastidiosa's ability to colonize the xylem vessels and disrupt the transport of water and nutrients from the root system to the canopy (Hopkins, 1995). It equally affects all sweet orange varieties and can be transmitted by leafhoppers, contaminated budwood, and seedlings (Rossetti et al., 1990). 
Plants with CVC showed a strong correlation between disease symptoms and disorders caused by water stress, according to the hypothesis of $X$. fastidiosa-induced xylem blockage (Machado et al., 1994). However, some other physiological changes are also possible. For instance, the induction of abscisic acid (ABA), commonly observed in plants with water stress as a sinalization to stress response, was not observed in plants with CVC (Gomes et al., 2003), and plants colonized by $X$. fastidiosa had lower photosynthetic rates (Ribeiro et al., 2003). These changes occur in plants before symptoms develop and are probably caused by low stomatal conductance, biochemical injuries to the photosynthetic machinery, and increase in alternative electron sinks (Ribeiro et al., 2003).

In order to understand the genetic responses resulting from the physiological changes that occur in plants displaying CVC symptoms, we constructed two EST libraries from sweet orange [Citrus sinensis (L.) Osbeck] trees, with and without CVC symptoms. The CVC symptomatic plant resulted from the $X$. fastidiosa infection. Using an in silico hybridization strategy, we found different genes that have significant variation in their transcript frequency. Understanding the role of these transcripts could help to explain the physiological changes that occur in plants with CVC.

\section{Materials and Methods}

\section{Preparation of cDNA libraries}

The libraries were prepared from mRNA isolated from leaves of Pera sweet orange [C. sinensis (L.) Osbeck] grafted on Rangpur lime (C. limonia Osbeck) 24 months after grafting and growing under greenhouse conditions. The leaves were collected from both non-inoculated and CVCdiseased plants at the same developmental stage. The diseased plants maintained under greenhouse were obtained by graft inoculation using infected material (buds from symptomatic branches) from a commercial orchard. From 6 to 8 months after inoculation, some infected plants showed CVC symptoms and the presence of bacteria was confirmed by PCR using $X$. fastidiosa specific primers (Pooler and Hartung, 1995).

Total RNA from leaves was extracted using Trizol reagent (Invitrogen). The Poly(A+) RNA was isolated from $1 \mathrm{mg}$ of total RNA with the polyATtract mRNA Isolation System (Promega Corporation, Madison, WI). The SuperScript Plasmid System with Gateway Technology for cDNA Synthesis and Cloning (Invitrogen) was used for the library construction. All the steps were done according to the manufacturers' instructions.

The sequencing reactions were performed using the Big Dye Terminator DNA sequencing Kit (Applied Biosystems). Sequencing was done in the ABI 3730 (Applied Biosystems).

\section{In silico hybridization and functional annotation}

For comparison of the libraries, we performed an in silico hybridization analysis. A total of 9,536 transcripts from the non-infected library and 6,408 from the infected library were analyzed. The in silico hybridization methodology included a clusterization of all transcripts from both libraries using the CAP3 tool (Huang and Madan, 1999) with the default parameters. Furthermore, the relative abundance of transcripts was calculated for each tentative consensus, normalizing abundances to 10,000 read libraries. The differential transcription was evaluated using statistical verification (Audic and Claverie, 1997). We considered differential expression as the possibility of a random transcript abundance distribution that for a given tentative consensus was equal to or less than $5 \%$. Automatic categorizations over the tentative consensus were performed as well, using the Munich Center for Proteins and Sequences Functional Categories (MIPS) v. 1.3 (http://mips.gsf.de/proj/ funcatDB/search main frame.html). Comparative genomics was carried out through tentative consensus comparison against the GenBank protein database, using the Blastall implementation of BLAST algorithm (Altschul et al., 1997).

\section{Results and Discussion}

\section{EST assembly and functional classification}

We obtained 15,944 ESTs, clusterized in 4,066 contigs (consensi sequences), by sequencing two cDNAs libraries constructed from non-inoculated and CVC-diseased sweet orange leaves. Thirty-seven contigs were identified with significant variation on transcription. This could result from either an increase in transcription levels or decrease in the turnover of the mRNAs. In this subset, 21 were up-regulated and 16 were down-regulated in plants with CVC (Table 1 and 2).

To further understand the physiological changes that occur in plants with CVC, we investigated the function of the differentially expressed genes in CVC plants. The contig sequences matching previously identified plant transcripts were automatically assigned to functional classes according to MIPS v. 1.3. Some transcripts had to be manually categorized based on the best match with BlastX. The largest class of sequences with known functions was predicted to play roles in metabolism (32\%). The majority of the remaining sequences were distributed among defense $(13 \%)$ and protein with unknown functions $(13 \%)$. The functional distribution of transcripts sequences was similar to that found in Theobroma cacao treated with inducers of defense response (Verica et al., 2004).

\section{Identification of down-regulated transcripts}

The main functional categories of the down-regulated genes in CVC-diseased plants were also associated to metabolism, protein modification, energy and transport facili- 
Table 1 - Functional categorization of the down-regulated genes in sweet orange plants exhibiting citrus variegated chlorosis symptoms

\begin{tabular}{|c|c|c|c|c|c|c|}
\hline \multirow{2}{*}{$\begin{array}{l}\text { Functional } \\
\text { category }\end{array}$} & \multirow[t]{2}{*}{$\mathrm{p}$ - value ${ }^{1}$} & \multicolumn{2}{|c|}{ Relative abundance of reads } & \multirow{2}{*}{$\begin{array}{c}\text { Match of genes up-regulated } \\
\text { by } X \text {. fastidiosa }\end{array}$} & \multirow[t]{2}{*}{ Organism } & \multirow{2}{*}{$\begin{array}{l}\text { Accession } \\
\text { number }^{2}\end{array}$} \\
\hline & & Without Xf & With Xf & & & \\
\hline \multirow[t]{6}{*}{ 01. Metabolism } & 0.0209 & 79.69 & 62.42 & $\begin{array}{l}\text { putative myo-inositol } \\
\text { 1-phosphate synthase }\end{array}$ & A. thaliana & AAC49172 \\
\hline & 0.0042 & 13.6 & 1.56 & putative acetyltransferase & A. thaliana & XP_468393 \\
\hline & 0.0000 & 12.58 & 0.00 & cytochrome P450 CYP98A1 & Sorghum bicolor & AAC39316 \\
\hline & 0.0004 & 14.68 & 0.00 & $\begin{array}{c}\text { glycosylasparaginase - like } \\
\text { protein }\end{array}$ & A. thaliana & CAB93711 \\
\hline & 0.0026 & 17.82 & 3.1211 & germin-like protein & Hordeum vulgare subsp. vulgare & CAC32847 \\
\hline & 0.0101 & 11.53 & 1.56 & pectinesterase & A. thaliana & AY143950 \\
\hline \multirow[t]{3}{*}{ 02. Energy } & 0.0003 & 19.92 & 1.56 & $\begin{array}{l}\text { light harvesting chlorophyll } \\
\text { a/b-binding protein }\end{array}$ & Nicotiana sylvestris & BAA25390 \\
\hline & 0.0360 & 61.87 & 51.49 & Rubisco activase & O.sativa & BAC78572 \\
\hline & 0.0059 & 9.43 & 0.00 & $\begin{array}{c}\text { photosystem I subunit } \mathrm{O} \\
\text { precursor }\end{array}$ & Guillardia theta & CAH04628 \\
\hline 05.Protein synthesis & 0.0366 & 30.41 & 20.28 & ribosomal protein & A. thaliana & 25407522 \\
\hline \multirow{2}{*}{$\begin{array}{l}\text { 06. Protein fate } \\
\text { (folding, modifica- } \\
\text { tion, destination) }\end{array}$} & 0.0235 & 9.43 & 1.56 & $\begin{array}{l}\text { FtsH metalloprotease - like } \\
\text { protein }\end{array}$ & O. sativa & BAD37477 \\
\hline & 0.0017 & 15.72 & 1.56 & putative subtilisin protease & O. sativa & XP_481633 \\
\hline $\begin{array}{l}\text { 11. Cell rescue, de- } \\
\text { fense and virulence }\end{array}$ & 0.0087 & 14.68 & 3.12 & $\begin{array}{l}\text { putative GDSL-motif } \\
\text { lipase/hydrolase protein }\end{array}$ & Agave americano & AAS75127.1 \\
\hline \multirow{2}{*}{$\begin{array}{l}\text { 67. Transport facili- } \\
\text { tation }\end{array}$} & 0.0042 & 13.63 & 1.56 & aquaporin PIP1b2 & Brassica oleracea & AAG23180 \\
\hline & 0.0256 & 19.92 & 9.36 & $\begin{array}{l}\text { putative aquaporin/plasma } \\
\text { membrane intrinsic protein }\end{array}$ & A.thaliana & AAN31817 \\
\hline 99. Unknown & 0.0462 & 53.48 & 46.81 & putative protein & A. thaliana & AAO33591. 1 \\
\hline
\end{tabular}

${ }^{1}$ Probability of having the putative gene differentially expressed only by chance (significant for $\mathrm{p}<0.05$ ).

${ }^{2}$ http://www.ncbi.nlm.nih.gov.

tation (Table 1). Among these genes, we found the heatinducible $\mathrm{FtsH}$, a pectinesterase, a germin-like protein and a hydroxylase-like cytochrome P450 (CYP98A3 family), proteins that could be directly involved in the response induced by the disease.

The heat-inducible ftsH gene encodes an ATPdependent protease targeted to plastids. This protein is considered a major enzyme involved in progressive degradation (gradual degradation of oligopeptides and amino acids) (Sakamoto, 2006). A common feature of light stress in plants, algae, and cyanobacteria is the light-induced damage of the photosystem II complex (PSII). The FtsH complex alone is able to degrade damaged subunits of this complex (Nixon et al., 2005). The transcripts related to photosynthesis were also down-regulated in plants with CVC. Previous research showed a decrease on net photosynthesis, transpiration, and respiration rates, stomatal conductance and leaf water potential in plants affected by CVC (Ribeiro et al., 2003). According to this author, in CVCdiseased plants the damage present in symptomatic leaves (chlorosis) together with the high resistance to water flux in xylem vessels are responsible for the decrease in photosyn- thesis. Moreover, Queiroz-Voltan and Paradela Filho (1999) found chloroplasts totally damaged in chlorotic regions present in CVC-symptomatic leaves. In fact, stress conditions may result in reduced repair of the PSII by inhibiting either the synthesis of ATP (Allakhverdiev et al., 2005 ) or the synthesis de novo of almost all of the lightinducible genes (Allakhverdiev et al., 2002) which somehow might affect the expression of FtsH, an ATP-dependent metalloprotease. Therefore the down-regulation of these photosynthesis-associated genes is perhaps a consequence of disorders that occur in the photosynthetic apparatus of CVC symptomatic plants. These observations indicate the existence of a complex network of regulatory interactions and coordination of photosynthesis in response to senescence. Also, other genes encoding components of the photosynthetic machinery such as a light harvesting chlorophyll a/b-binding protein, rubisco activase and photosystem I subunit O precursor, were down-regulated in plants with CVC.

In addition, the ESTs analyses also showed one transcript involved in carbohydrate metabolism (pectinesterase). This transcript was significantly repressed under 
Table 2 - Functional categorization of the up-regulated genes in sweet orange plants exhibiting citrus variegated chlorosis symptoms

\begin{tabular}{|c|c|c|c|c|c|c|}
\hline \multirow{2}{*}{$\begin{array}{l}\text { Functional } \\
\text { category }\end{array}$} & \multirow[t]{2}{*}{$\mathrm{p}$ - value ${ }^{1}$} & \multicolumn{2}{|c|}{ Relative abundance of reads } & \multirow{2}{*}{$\begin{array}{l}\text { Match of genes up-regulated } \\
\text { by } X \text {. fastidiosa }\end{array}$} & \multirow[t]{2}{*}{ Organism } & \multirow{2}{*}{$\begin{array}{l}\text { Accession } \\
\text { number }\end{array}$} \\
\hline & & Without Xf & With Xf & & & \\
\hline \multirow[t]{5}{*}{ 01.Metabolism } & 0.0000 & 9.43 & 53.05 & $\begin{array}{l}\text { isoflavone reductase related } \\
\text { protein }\end{array}$ & Populus trichocarpa & CAA06709 \\
\hline & 0.0002 & 1.04 & 17.16 & $\begin{array}{l}\text { isoflavone reductase-like } \\
\text { protein }\end{array}$ & $\begin{array}{c}\text { Populus balsamifera subsp. } \\
\text { trichocarpa }\end{array}$ & CAA06709 \\
\hline & 0.0000 & 7.34 & 95.19 & $\begin{array}{l}\text { xyloglucan endotrans- } \\
\text { glycosylase related protein }\end{array}$ & Medicago truncatula & AAU89382 \\
\hline & 0.0040 & 3.14 & 15.60 & $\begin{array}{l}\text { putative polygalacuronase } \\
\text { isoenzyme } 1 \text { beta subunit }\end{array}$ & Bruguiera gymnorrhiza & BAB 60850 \\
\hline & 0.0002 & 0.00 & 14.04 & ankyrin-like protein & A. thaliana & BAB02273 \\
\hline 02. Energy & 0.0225 & 1.04 & 7.80 & $\begin{array}{l}\text { Phosphoribulokinase, chloropl } \\
\text { ast precursor }\end{array}$ & O. sativa & XP_462675 \\
\hline $\begin{array}{l}\text { 08. Cellular transport } \\
\text { and transport mecha- } \\
\text { nisms }\end{array}$ & 0.0025 & 0.00 & 9.36 & $\mathrm{ABC} 1$ transporter like protein & Nicotiana plumbaginifolia & CAC40990 \\
\hline $\begin{array}{l}\text { 10. Cellular commu- } \\
\text { nication/signal trans- } \\
\text { duction mechanism }\end{array}$ & 0.0025 & 0.0 & 9.36 & $\begin{array}{l}\text { leucine-rich repeat protein } \\
\text { putative }\end{array}$ & $\begin{array}{l}\text { Citrofortunella mitis } \\
\quad \text { (calamondin) }\end{array}$ & AAP23944 \\
\hline \multirow[t]{5}{*}{$\begin{array}{l}\text { 11. Cell rescue, de- } \\
\text { fense and virulence }\end{array}$} & 0.0063 & 0.00 & 7.80 & $\begin{array}{l}\text { drought-inducible cysteine } \\
\text { proteinase RD21A precursor }\end{array}$ & Pisum sativum & CAC41636 \\
\hline & 0.0025 & 4.19 & 18.72 & $\begin{array}{l}\text { putative GDSL-motif } \\
\text { lipase/hydrolase protein }\end{array}$ & Agave americana & AAS75127.1 \\
\hline & 0.0002 & 0.00 & 14.04 & putative lipoxygenase & Lycopersicon esculentum & CAA05280 \\
\hline & 0.0327 & 32.50 & 43.69 & putative peroxidase & A. thaliana & CAA66961 \\
\hline & 0.0000 & 0.00 & 29.65 & $\begin{array}{c}\mathrm{Cu} / \mathrm{Zn} \text { superoxide } \\
\text { dismutase-like protein }\end{array}$ & $\begin{array}{c}\text { Populus tremula } \mathrm{x} \text { Populus } \\
\text { tremuloides }\end{array}$ & CAC33845 \\
\hline $\begin{array}{l}13 \text { Regulation of / in- } \\
\text { teraction with cellular } \\
\text { environment }\end{array}$ & 0.0388 & 0.00 & 4.68 & metallothionein-like protein & Elaeis guineensis & CAB52585 \\
\hline 14 Cell fate & 0.0025 & 0.00 & 9.36 & protein disulphide isomerase & Zea mays & AAX09961 \\
\hline $\begin{array}{l}\text { 25.Development } \\
\text { (systemic) }\end{array}$ & 0.0010 & 0.00 & 10.92 & pollen specific protein SF21 & A. thaliana & AAD10160 \\
\hline $\begin{array}{l}\text { 63. Protein with } \\
\text { binding function }\end{array}$ & 0.0000 & 4.19 & 63.98 & lectin-related protein precursor & Citrus x paradisi & $\mathrm{gb} \mid \mathrm{AAG} 38522.1$ \\
\hline \multirow[t]{4}{*}{ 99. Unknown } & 0.0002 & 1.04 & 17.16 & putative protein & A. thaliana & AT5G26220 \\
\hline & 0.0025 & 0.00 & 9.36 & putative protein & A. thaliana & AT1G47330 \\
\hline & 0.0004 & 0.00 & 12.48 & putative protein & A. thaliana & AT1G29050 \\
\hline & 0.0088 & 5.24 & 17.16 & putative protein & A. thaliana & AT2G05540 \\
\hline
\end{tabular}

${ }^{1}$ Probability of having the putative gene differentially expressed only by chance (significant for $\mathrm{p}<0.05$ ).

${ }^{2} \mathrm{http}: / /$ www.ncbi.nlm.nih.gov, for the unknown proteins accession number refers to http://mips.gsf.de/cgi-bin/proj/thal/search_gene.

CVC condition. Some carbohydrates are part of the plant cell wall, making up to $90 \%$ of its composition. These carbohydrates can be divided into three groups: cellulose, hemicellulose, and pectin (Vries and Visser, 2001). This transcript might represent a gene involved in pectin metabolism. Pectin and pectin changes affect cell wall strength, porosity, ion-exchange capacity, cell adhesion, and other aspects of plant development and pathogen response (Guan and Nothnagel, 2004). Hence, a repression in carbohydrate metabolism, mainly pectin, could facilitate the bacterial colonization of the vessels.
Cytochrome P450 monooxygenases from the CYP98 family catalyze the meta-hydroxylation step in the phenylpropanoid biosynthetic pathway, and repression in such a gene may lead to reduction of plant defense and production of some phenolic compounds, modification of lignin composition and impairment in plant development (Abdulrazzak et al., 2006). Hence, the down-regulation of this gene may be partially involved in the symptoms observed in plants with CVC, which include reduction in fruit size and poor development of plants. 
Similarly, germin-like proteins are involved not only in stress response but also in plant development and cell wall biogenesis, C-compound and carbohydrate catabolism, osmotic regulation, photoperiodic oscillation, and defense as well (Çaliskan, 2000; Patnaik and Khurana, 2001). According to the automated categorization based on the MIPS, confirmed by a manual analysis, the germin-like protein gene that was repressed in plants with CVC is likely to be involved in C-compound carbohydrate catabolism and/or stress response, biogenesis of cellular components, and/or energy (respiration). Therefore, repression of such an important gene could possibly lead to various effects in the plant, including the reduction in growth and development observed in symptomatic plants.

In our experiment, two types of membrane transporter facilitator transcripts were down-regulated during the pathogen infection. Many aquaporins act as water channels and are thought to play an important role in plant water relations. One of the subfamilies of the aquaporins, the plasma membrane intrinsic proteins, are generally downregulated in leaves of plants under a gradual water stress (Alexandersson et al., 2005). This is probably the same situation occurring in plants with CVC.

\section{Identification of up-regulated transcripts}

The majority of the up-regulated transcripts in plants with CVC were associated to metabolism and defense response (Table 2). Among the transcripts functionally categorized as carboydrate metabolism, one contig coding was identified for a protein with xyloglucan endotransglycolase/hydrolase activity (XTH) (EC 2.4.1.207). The corresponding transcript was 13 -fold more abundant in infected compared to non-infected leaves. These proteins are encoded by a multigene family (Xu et al., 1996; Rose et al., 2002) including an Arabidopsis touch gene named TCH4 that encodes a xyloglucan endotransglycosylase (Xu et al., 1995). Since $X T H \mathrm{~s}$ are capable of modifying the plant cell wall and $\mathrm{TCH}$ genes are involved in responses to environmental stimuli, xyloglucan endotransglycosylases/hydrolases are thought to play important roles altering cell wall properties in response to environmental stresses (Braam et al., 1997). Indeed, Xu et al. (1996) showed that expression of $T C H 4$ is dramatically up-regulated in response to several environmental stimuli as well as the growth-enhancing hormones, auxin and brassinosteroids. In addition, the authors found different sensitivities of the XTH genes to environmental and hormonal stimuli. They concluded that differential regulation of expression of this complex gene family suggests a recruitment of related cell wall-modifying enzymes that may control the properties of cell walls and tissues during development and in response to environmental cues. Induction of an $X T H$ herein presented in response to $X$. fastidiosa suggests some kind of reorganization of cell walls during the development of $\mathrm{CVC}$ as a consequence of the whole stress response observed. It has been postulated that $X T H$ s carry out various functions, including wall loosening, wall strengthening, integrating new xyloglucans into the wall, trimming xyloglucan strands that are not tightly stuck to the surface of cellulose, fruit softening, and hydrolysing xyloglucans particularly during xylem formation. However, it is only clear that xyloglucan endotransglucosylase cuts and joins xyloglucans (reviewed by Cosgrove, 2005). The consequences of this biochemical activity for wall properties under CVC condition still needs further investigation.

Infected plants also showed induction of transcripts representing putative defense- and stress-related genes that code for protein disulfide isomerase, peroxidase, superoxide dismutase, metallothionein-like protein, dehydration-responsive protein RD22, ankyrin-like protein, lipase, lipoxygenase and isoflavone reductase-like proteins.

Cells monitor protein misfolding and trigger rapid responses to a variety of abiotic stresses (Rao and Bredesen, 2004). One of these events is the endoplasmic reticulum (ER) stress that results from the accumulation of unfolded or misfolded protein in the ER. This stress activates signal transduction pathways in an attempt to maintain osmeostasis of the ER and are known as the unfolded protein response (UPR); this results in a rapid adjustment of chaperone levels and redox activation or accumulation of stressspecific chaperones (Winter and Jakob, 2004). UPR involves the participation of protein disulfide isomerases (PDIs), which are well-known molecular chaperones (Wilkinson and Gilbert, 2004). This type of chaperones contains thioredoxin (TRX) domains that help the formation of proper disulfide bonds during protein folding (Houston et al., 2005). The induction of a gene encoding a PDI in CVC diseased plants could reflect a disorder in ER homeostasis and a need for an increase in the correct folding of proteins.

Plants express a large number of isoenzymes modulated by signals related to cellular detoxification of reactive oxygen species, which may accumulate for different reasons, including wounding or pathogen attack (Dietz et al., 2006). Transcripts representing genes involved with oxidative stress were up-regulated in plants with CVC, such as Peroxidases and Copper/Zinc superoxide dismutase. The function of either class of enzyme remains only speculative on citrus trees affected by $X$. fastidiosa. Peroxidases act on hydrogen peroxide $\left(\mathrm{H}_{2} \mathrm{O}_{2}\right)$ and Superoxide dismutase catalyzes the conversion of superoxide radicals $\left(\mathrm{O}_{2}{ }^{-}\right)$to hydrogen peroxide and molecular oxygen $\left(\mathrm{O}_{2}\right)$. Three distinct evolutionary families of Superoxide dismutase are known, and the Copper/Zinc binding family is one of them (Lin et al., 2002). In CVC affected trees, xylem vessels are partially blocked, or sectored, by bacterial biofilm (Souza et al., 2005). In response, the tree may modulate the level of superoxide radicals $\left(\mathrm{O}_{2}{ }^{-}\right)$, triggering Superoxide dismutase to produce hydrogen peroxide, which can further react with the phenol group of monolignol, in the presence of peroxidase, to produce lignin components. Lignin gives me- 
chanical strength to plant tissues such as xylem vessels, and may also function in defense for the same reason. Lignin is formed in many plants in response to wounding. Therefore, it is possible that $\mathrm{CVC}$ affected plants orchestrate related genes which attempt to restrain additional infections and potential enzymatic damage caused by $X$. fastidiosa biofilm.

A gene encoding a putative metallothionein protein, up-regulated in the citrus plants infected with X. fastidiosa, is probably related to the homeostasis of metal ions or heavy metal binding $(\mathrm{Cu}, \mathrm{Fe}$, and $\mathrm{Zn})$. According to Rauser (1999), during sap translocation from the root system to the leaves, through the xylem, citrate and histidine are the main ligands for $\mathrm{Cu}, \mathrm{Ni}$, and $\mathrm{Zn}$. Possibly, the presence of these putative up-regulated genes in plants with CVC could be related to a strategy of the plant to keep the transport of these ions to supply the nutritional deficit, since the presence of the pathogen causes obstruction of the vessels and consequent reduction in nutrient transport.

There are other transcripts possibly induced by the stress condition caused by CVC, such as the dehydration-responsive protein $\mathrm{RD} 22$. The up-regulation of this gene could be related to a typical response to drought observed in plants with CVC. This protein was shown to be induced by ABA (Abe et al., 1997). Synthesis of ABA is not a feature of plants with CVC (Gomes et al., 2003) and therefore the physiological conditions are different. This was evidenced in our analysis where only this gene, related to ABA, showed differential expression. Moreover, it seems to respond to different stimuli and protect the plant in adverse conditions (Abe et al., 1997). Another putative gene, possibly up-regulated due to the damage caused by water stress, was an ankyrin-like protein. This gene has high sequence similarity to a locus tagged on chromosome 3 of Arabidopsis thaliana (AT3G23300) with a putative methyltransferase function. The DNA methyltransferase (DNA MTase) family of enzymes catalyzes the transfer of a methyl group to DNA, which serves for a wide variety of biological functions, spanning from epigenetic events in mammals (Pradhan and Esteve, 2003) to general transcriptional repression, and consequently gene regulation, in different eukaryote organisms (Goll and Bestor, 2005). Analysis using the Conserved Domain Search (NCBI) also indicated the presence of a methyltransferase domain in the citrus ankyrin-like protein. Regarding the potential triggering events, the AT3G23300 locus codes for a dehydration-responsive protein which is similar to the early-responsive dehydration stress ERD3 protein, also from $A$. thaliana. In the case of citrus plants affected by $X$. fastidiosa, trees undergo visible stress, commonly displaying symptoms of twig die back, overall lack of vigor and changes in fruit size and quality. Thus, it is possible that the gene represented by ankyrin-like responds to $X$. fastidiosa as would happen under a dehydration condition. If that is true, maybe affected plants would then modify patterns of gene expression in several pathways using methylation process: the ankyrin-like related gene would play a role at least in some subset of responsive genes related to the symptoms seen on affected branches or in the whole tree in severe cases.

Transcripts representing genes with homology to lipoxygenase and a lipase with a GDSL motif (GDSLlipase) were significantly up-regulated in CVC-diseased plants when compared to non-inoculated ones. However, a possible isoform of GDSL-lipase was also down-regulated in the same conditions (Table 1). The alignment of the two different GDSL-lipase using the Blast2seq tool showed that they diverge significantly in their $\mathrm{N}$-terminal portion, but are rather well conserved in their C-terminal part, including the GDSL motif. The alignment also shows that they have $76 \%$ of identical residues and $86 \%$ of positive residues in the conserved region. At the nucleotide level they also show $76 \%$ of identical residues in the regions showing similarity. However, there is also a region in the middle of the sequences that does not align since it is not conserved. Therefore these two proteins are different isoforms that may have distinct functions depending on the environmental conditions to which the plant is exposed. In addition, genes with homology to lipases were found to be required for SA-dependent induction of defense responses (SAR) (Jakab et al., 2003). Lipoxygenases catalyze the formation of compounds involved in plant defense responses, acting as either signaling molecules for wound-induced responsive genes or as antimicrobial substances (León et al., 2002; Roopashree et al., 2006).

Two transcripts representing genes that code for isoflavone reductase-like proteins were found to be significantly up-regulated under CVC condition. It has been long known that phenylpropanoids - and isoflavonoids in particular - are involved in the production of phytoalexins and, hence, antimicrobial activities (Preisig et al., 1990; Nicholson and Hammerschmidt, 1992; Tahara and Ibrahim, 1995). Therefore, over-expression of genes involved in isoflavonoid biosynthesis might be expected as a response of the plant to infection.

\section{Concluding Remarks}

The presence of $X$. fastidiosa in susceptible plants leads to CVC. This disease induces water and nutritional stresses that are part of the physiological changes observed in the plants. These changes lead to modification of the gene expression pattern by either increasing or decreasing the levels of several different transcripts. Among the down-regulated genes, four were related with photosynthesis, possibly reflecting the phenotype of chlorophyll degradation observed in plants with CVC. However, sweet orange infected with $X$. fastidiosa, but displaying no CVC symptoms, showed up-regulation of several genes associated with photosynthesis, probably as a result of genetic responses of the plant to the damage caused by the bacterium 
(Souza et al., this issue). According to Ribeiro et al. (2003), sweet orange plants infected with $X$. fastidiosa showed reduction in photosynthesis before the development of symptoms.

Regardless of the damage caused by $\mathrm{CVC}$, this disease does not kill affected plants. There may be adaptation mechanisms that could help to keep the plants alive. Genes related to reorganization of cell walls, ions transport and water stress were up-regulated in plants with CVC and could participate in this process.

The transcripts up-regulated in plants with CVC associated with defense response suggest that the sweet orange plants activate their defense machinery, which is not sufficient to block the disease. The whole process of pathogen recognition may be triggered later, after the bacteria are already established within the plant, a common characteristic in susceptible response to pathogen. Another possibility is that these genes are expressed as a secondary response due to the physiological effect caused by the infection, like nutritional and water stress.

\section{Acknowledgments}

The research was supported by Conselho Nacional de Desenvolvimento Científico e Tecnológico (CNPq, Instituto do Milênio). A.A.S., M.A.T., H.D.C-F., M.L.P.N.T. and M.A.M. are recipient of a research fellowship from CNPq.

\section{References}

Abdulrazzak N, Pollet B, Ehlting J, Larsen K, Asnaghi C, Ronseau S, Proux C, Erhardt M, Seltzer V, Renou JP, et al. (2006) A coumaroyl-ester-3-hydroxylase insertion mutant reveals the existence of nonredundant meta-hydroxylation pathways and essential roles for phenolic precursors in cell expansion and plant growth. Plant Physiol 140:30-48.

Abe H, Yamaguchi-Shinozaki K, Urao T, Iwasaki T, Hosokawa D and Shinozaki K (1997) Role of Arabidopsis MYC and MYB homologs in drought-and abscisic acid-regulated gene expression. Plant Cell 9:1859-1868.

Alexandersson E, Fraysse L, Sjovall-Larsen S, Gustavsson S, Fellert M, Karlsson M, Johanson U and Kjellbom P (2005) Whole gene family expression and drought stress regulation of aquaporins. Plant Mol Biol 59:469-84.

Allakhverdiev SI, Nishiyama Y, Miyairi S, Yamamoto H, Inagaki N, Kanesaki Y and Murata N (2002) Salt stress inhibits the repair of photodamaged photosystem II by suppressing the transcription and translation of psbA genes in Synechocystis. Plant Physiol 130:1443-453.

Allakhverdiev SI, Nishiyama Y, Takahashi S, Miyairi S, Suzuki I and Murata N (2005) Systematic analysis of the relation of electron transport and ATP synthesis to the photodamage and repair of photosystem II in Synechocystis. Plant Physiol 137:263-273.

Altschul SF, Madden TL, Schaffer AA, Zhang J, Zhang Z, Miller W and Lipman DJ (1997) Gapped BLAST and PSI-BLAST: A new generation of protein database search programs. Nucleic Acids Res 17:3389-3402.
Audic S and Claverie JM (1997) The significance of digital gene expression profiles. Genome Res 7:986-995.

Braam J, Sistrunk ML, Polisensky DH, Xu W, Purugganan MM, Antosiewicz DM, Campbell P and Johnson KA (1997) Plant responses to environmental stress: Regulation and functions of the Arabidopsis TCH genes. Planta 203:S35-S41.

Çaliskan M (2000) Germin, an oxalate oxidase, has a function in many aspects of plant life. Turk J Biol 24:717-724.

Cosgrove DJ (2005) Growth of the plant cell wall. Nature Rev Mol Cell Biol 6:850-861.

Dietz KJ, Jacob S, Oelze ML, Laxa M, Tognetti V, de Miranda SM, Baier M and Finkemeier I (2006) The function of peroxiredoxins in plant organelle redox metabolism. J Exp Bot 57:1697-1709.

Goll MG and Bestor TH (2005) Eukaryotic cytosine methyltransferase. Annu Rev Biochem 74:481-514.

Gomes MMA, Lagôa AMMA, Machado EC and Medina CL (2003) Abscisic acid and indole-3-acetic acid contents in orange trees infected by Xylella fastidiosa and submitted to cycles of water stress. Plant Growth Regulation 39:263-270.

Guan Y and Nothnagel EA (2004) Binding of arabinogalactan proteins by yariv phenylglycoside triggers wound-like responses in Arabidopsis cell cultures. Plant Physiol 135:1346-1366.

Hopkins DL (1995) Xylella fastidiosa. In: Pathogenesis and host specificity in plant diseases. Singh US, Singh RP and Kohmoto K (eds) Histopathological, Biochemical, Genetic and Molecular Bases. v. I - Prokaryotes. Elsevier Science Ltda, Great Britain, pp 185-197.

Houston NL, Fan C, Xiang QY, Schulze JM, Jung R and Boston RS (2005) Phylogenetic analyses identify 10 classes of the protein disulfide isomerase family in plants, including single-domain protein disulfide isomerase-related proteins. Plant Physiol 137:762-778.

Huang X and Madan A (1999) CAP3: A DNA Assembly Program. Genome Res 9:868-877.

Jakab G, Manrique A, Zimmerli L, Métraux J-P and Mauch-Mani B (2003) Molecular characterization of a novel lipase-like pathogen-inducible gene family of Arabidopsis. Plant Physiol 132:2230-2239.

León J, Royo J, Vancanneyt G, Sanz C, Silkowski H, Griffiths G and Sánchez-Serrano JJ (2002) Lipoxygenase H1 gene silencing reveals a specific role in supplying fatty acid hydroperoxides for aliphatic aldehyde production. J Biol Chem 277:416-423.

Lin MW, Lin MT and Lin CT (2002) Copper/zinc-superoxide dismutase from lemon cDNA and enzyme stability. J Agric Food Chem 50:7264-7270.

Machado EC, Quaggio JA, Lagôa AMMA, Ticelli M and Furlani PR (1994). Trocas gasosas e relações hídricas em laranjeiras com clorose variegada dos citros. Rev Bras Fisiol Veg 6:5357.

Nicholson RL and Hammerschmidt R (1992) Phenolic compounds and their role in disease resistance. Annu Rev Phytopathol 30:369-389.

Nixon PJ, Barker M, Boehm M, de Vries R and Komenda J (2005) FtsH-mediated repair of the photosystem II complex in response to light stress. J Exp Bot 56:357-363.

Patnaik D and Khurana P (2001) Germins and germin like proteins: An overview. Indian J Exp Biol 39:191-200. 
Pooler MR and Hartung JS (1995) Specific PCR detection and identification of Xylella fastidiosa strains causing citrus variegated chlorosis. Curr Microbiol 31:377-381.

Pradhan S and Esteve PO (2003) Mammalian DNA (cytosine-5) methyltransferases and their expression. Clin Immunol 109:6-16

Preisig CL, Bell JN, Sun Y, Hrazdina G, Matthews DE and VanEtten HD (1990) Biosynthesis of the phytoalexin pisatin isoflavone reduction and further metabolism of the product sophorol by extracts of Pisum sativum. Plant Physiol 94:1444-1448.

Queiroz-Voltan RB and Paradela-Filho O (1999) Caracterização de estruturas anatômicas de citros infectados com Xylella fastidiosa. Laranja 20:55-76.

Rao RV and Bredesen DE (2004) Misfolded proteins, endoplasmic reticulum stress and neurodegeneration. Curr Opin Cell Biol 16:653-662.

Rauser WE (1999) Structure and function of metal chelators produced by plants: The case for organic acids, amino acids, phytin, and metallothioneis. Cell Biochem Biophys 31:1948.

Ribeiro RV, Machado EC and Oliveira RF (2003) Early photosynthetic responses of sweet orange plants infected with Xylella fastidiosa. Physiol Mol Plant Pathol 62:167-173.

Roopashree S, Singh SA, Gowda LR and Rao AGA (2006) Dualfunction protein in plant defence: Seed lectin from Dolichos biflorus (horse gram) exhibits lipoxygenase activity. Biochem J 395:629-639.

Rose JK, Braam J, Fry SC and Nishitani K (2002) The XTH family of enzymes involved in xyloglucan endotransglucosylation and endohydrolysis: Current perspectives and a new unifying nomenclature. Plant Cell Physiol 43:1421-1435.
Rossetti V, Garnier M, Bove JM, Beretta MJG, Teixeira ARR, Quaggio JA and Denegri JD (1990) Occurrence of xylemrestricted bacteria in sweet orange trees affected by chlorotic variegation, a new citrus disease in Brazil. C R Acad Sci III Sci Vie 310:345-349.

Sakamoto W (2006) Protein degradation machineries in plastids. Annu Rev Plant Biol 57:599-621.

Souza AA, Takita MA, Pereira EO, Coletta-Filho HD and Machado MA (2005) Expression of pathogenicity-related genes of Xylella fastidiosa in vitro and in planta. Curr Microbiol 50:223-228.

Tahara S and Ibrahim RK (1995) Prenylated isoflavonoids - An update. Phytochemistry 38:1073-1094.

Verica JA, Maximova SN, Strem MD, Carlson JE, Bailey BA and Guiltinan MJ (2004) Isolation of ESTs from cacao (Theobroma cacao L.) leaves treated with inducers of the defense response. Plant Cell Rep 6:404-413.

Vries RP and Visser J (2001) Aspergillus enzymes involved in degradation of plant cell wall polysaccharides. Microbiol Mol Biol Rev 65:497-522.

Wilkinson B and Gilbert HF (2004) Protein disulfide isomerase. Biochim Biophys Acta 1699:35-44.

Winter J and Jakob U (2004) Beyond transcription-new mechanisms for the regulation of molecular chaperones. Crit Rev Biochem Mol Biol 39:297-317.

Xu W, Purugganan MM, Polisensky DH, Antosiewicz DM, Fry SC and Braam J (1995) Arabidopsis TCH4, regulated by hormones and the environment, encodes a xyloglucan endotransglycosylase. Plant Cell 7:1555-1567.

Xu W, Campbell P, Vargheese AK and Braam J (1996) The Arabidopsis XET-related gene family: Environmental and hormonal regulation of expression. Plant J 9:879-89.

Associate Editor: Reinaldo Montrazi Barata 